\title{
Saints, Martyrs, and the Reformation: Reflections on Robert Bartlett's Why Can the Dead Do Such Great Things?
}

\section{Euan CAmeron}

$\mathrm{R}$ OBERT Bartlett's book on the cult of saints in the Middle Ages clearly constitutes a major achievement. Its scope is vast; its approach ranges from the chronological to the thematic; it embraces many cultural, as well as theological and religious, aspects of the subject. Finally, it is informed by a rich comparative vision that includes wide-ranging discussion of other religions.

Nevertheless, it devotes most attention to an area of primary focus, which comprises western Europe in the High and Later Middle Ages, broadly understood. In this period the conviction was widespread (though not quite universal, as Bartlett shows) that outstandingly holy people were in paradise with God; that they knew of and responded to the requests made for intercession by their devotees; and that they might become specialists, either in terms of the needs that they addressed or the geographical or ethnic areas which they served. This was also the period of the great collections of lives of saints, above all the thirteenth-century compilation known as the Golden Legend. As Bartlett remarks in a particularly interesting insight on page 504, while some of the literature emphasized that saints were fellow human beings, accessible to imitation by the devout and virtuous faithful, evidence rather suggests that for many if not most people, the saints served as supernatural helpers and protectors rather than as examples.

As a specialist only in the latest chronological period covered in Bartlett's book, I hope to offer just a few thoughts related to the question of the saints and the Reformation, and the question of sainthood after 1500 more generally. At the outset, allow me to say that Bartlett's fourth chapter, which addresses fairly briefly the impact of the Reformation on the cult of saints, seems quite admirable, and there is nothing here to suggest that the claims and judgments made in that chapter need radical revision.

However, it may be helpful to add a few additional thoughts regarding the very end of the period covered by Bartlett's book. This paper will make a few suggestions and raise a few possibilities in three general areas. First, I shall review some of the theological objections to the idea of "sanctity" in the Protestant Reformation and how those objections derived from the very 
heart of the Reformation message. Second, I shall offer a summary of the historical view of the cult of saints found in one of the most extensive Protestant treatments of the subject, Heinrich Bullinger's On the Origin of Error of 1539. Third, I should like to speculate on how martyrologies and commemorations may have filled some of the cultural space vacated by sainthood in the medieval Catholic sense. Finally, this paper will offer a few thoughts on what has happened to sainthood in the modern centuries.

The Protestant reformers had no objection to the word "saint." Sanctus meant no more than holy, which all serious Christians hoped to become. However, the Protestant doctrine of righteousness, fully imputed by grace, but only ever partially imparted by the Holy Spirit in this life, absolutely determined that the understanding of sanctus would be quite different from that of the Middle Ages. The crucial point was that no living Christian believer ever attained sufficient merit for salvation, let alone surplus merit, even with the utmost cooperation of divine grace. To take just a few examples, Philipp Melanchthon wrote: "The saints have a twofold nature, spirit and flesh ... we are saints insofar as we are spirit . . . sin still adheres in the flesh." John Calvin was equally graphic: "Sin ceases only to reign; it does not also cease to dwell in [the regenerate] . . . we have not a single work going forth from the saints that . . . deserves not shame as its just reward." Finally, Martin Bucer stated in 1548: "Sin . . . is still so powerful that we can possess neither faith, hope nor love . . . to the degree of perfection justly enjoined upon us ... all the saints . . must still ask God . . for the remission of their debts." 45

The term "saint" was used very liberally, in Protestant theology from Luther onwards, to describe the viator, the ordinary Christian who is saved by grace, and saved in hope of a regeneration to be completed in a future life. Martin Luther very early on redefined the communion of saints as the spiritual community of the truly faithful here on earth. ${ }^{46}$ The reformers were quite willing to contradict even their favorites among the early fathers, in order to be consistent on this point. John Calvin confronted the argument used by Jerome against Vigilantius that the saints triumphant in heaven must feel the same charity towards the living faithful as they expressed in their earthly lives. This claim involved, Calvin argued, unwarranted speculation about the state of the future life. ${ }^{47}$ In fact, there was considerable disorder among the

\footnotetext{
${ }^{45}$ Philipp Melanchthon, "Loci Communes," in Melanchthons Werke in Auswahl, ed. Robert Stupperich (Gütersloh: C. Bertelsmann, 1951-), vol. II part I, pp. 136-137, also 108, 265; John Calvin, Institutes III. iii. 11; xiv. 9; xv; Martin Bucer, Résume sommaire de la doctrine Chrétienne, ed. and trans. François Wendel (Paris: Presses Universitaires de France, 1951), 42-43.

${ }^{46}$ Paul Althaus, The Theology of Martin Luther, trans. Robert C. Schultz (Philadelphia, Pa.: Fortress Press, 1966), 297-303.

${ }^{47}$ Calvin, Institutes III. xx. 21-27.
} 
reformers' beliefs about the post-mortem existence of the human being. Martin Luther appears to have envisaged a period of sleep after death, before the returning Christ would come to him and call out "Doctor Martin, get up!"48

Other aspects of the Reformation program tended to invalidate the medieval cult of saints. Though controversial even in its own time, the belief had tended to grow up in the later Middle Ages that addressing the right saint in the right manner with the right level of consistent devotion would ensure not just spiritual, but tangible, physical benefits. ${ }^{49}$ Prayer, in the Reformation (and one might add, for some authors of the Catholic reform as well) was strictly petitionary and addressed only to God. Moreover, the petitioner was warned that a provident God might well choose not to respond to the prayer in the way requested. Little if any of these arguments were exclusive to the Reformation: some late medieval critics of "superstitious" prayer such as Gerson had raised the same objections. What was new was the absolute onesided unanimity with which Protestants made those arguments.

Heinrich Bullinger (1504-1575) antistes or leader of the Zürich church from the death of Zwingli in 1531 to his own death forty-four years later, exercised considerable authority over the reformed tradition in German-speaking Switzerland and also in England, where his works were translated and widely used. ${ }^{50}$ Bullinger compiled his two-part polemical tract On the Origin of Error in the late 1520s and 1530s, focusing on two aspects of medieval worship: first, the cult of saints, and second, the medieval understanding of the Eucharist or the Mass. ${ }^{51}$

Bullinger approached the history of the medieval church with the assumption that in the era of primitive Christianity, all was very simple and very pure. The elaborations that occurred over succeeding centuries degraded and depraved the pristine simplicity of the religious life. All religions, he believed, were

\footnotetext{
${ }^{48}$ James Kroemer, “'Doctor Martin, Get Up': Luther's View of Life after Death" in On the Apocalyptic and Human Agency: Conversations with Augustine of Hippo and Martin Luther, eds. Kirsi Stjerna and Deanna A. Thompson (Newcastle upon Tyne, UK: Cambridge Scholars Publishing, 2014), 33-50. On the subject more broadly, see for example Norman T. Burns, Christian Mortalism from Tyndale to Milton (Cambridge, Mass.: Harvard University Press, 1972).

${ }^{49}$ For both sides of the debate see Johannes Nider's Formicarius, bk. 4 ch. 2, in Johannis Nideri theologi olim clarissimi de visionibus ac revelationibus: opus rarissimum historiis Germanice refertissimum, anno 1517, Argentince editum (Helmstedt, 1692), 414-424.

${ }^{50}$ See Diarmaid MacCulloch, "Bullinger and the English-Speaking World" in Heinrich Bullinger: Life - Thought - Influence, eds. Emidio Campi and Peter Opitz (Zürich: Theologischer Verlag, 2007), ii, 891-934.

${ }^{51}$ Heinrich Bullinger, De Origine Erroris Libri Duo . . . In priore agitur de Dei veri iusta invocatione et culto vero, de Deorum item falsorum religionibus et simulachrorum cultu erroneo. In posteroiore disseritur de Institutione et vi sacrae Coenae domini, et de origine et progressu Missae Papisticae, contra varias superstitiones pro religione vera antiqua et orthodoxa (Zurich: Froschauer, 1539).
} 
monotheistic in their primordial state, but all showed a tendency to deteriorate into the worship of subsidiary deities or spiritual beings. ${ }^{52}$

The gradual decline in Christian purity manifested itself even among the fathers. However, Bullinger was fairly certain that sometimes they were misreported: They "believed that such people must be concerned for our salvation as they were in life; they did not teach that we were to ask them for things, place trust, give veneration, invocation and worship to them." 53 Bullinger spent some time dismantling the arguments used, for instance, by Jerome against Vigilantius on this subject. ${ }^{54}$ However, the rot had really set in with the barbarian invasions, which Bullinger believed caused a decline in the sophistication and understanding of the church's leaders. Given that the bishops were more ignorant than their predecessors, no one was learned enough to prevent the spread of idolatry through the cult of images of saints. ${ }^{55}$ Bullinger then presented a brief, condensed and highly tendentious history of the iconoclastic controversy in the East, which he held responsible for the division between the Eastern and the Western Churches. ${ }^{56}$

After a theological excursus against idolatry, Bullinger embarked on a comparison between the cult of saints in the Middle Ages and the worship of subsidiary deities in paganism. As Bartlett has shown, this argument was known and confronted in late antiquity: some leaders of the church were perfectly content, even proud, to say that their saints had replaced the false gods of the pagans. However, in the Enlightenment the argument developed that images and statues of saints were devised in the time of mass conversions after the end of the persecutions, to make the transition to Christianity easier for pagan converts. Thus the saints were "really" "only" the pagan gods transformed and replicated. ${ }^{57}$ This argument was by no means original to Enlightenment thinkers such as David Hume. In fact (like many anticlerical arguments deployed by the philosophes) it derived from the Renaissance humanists and the Protestant reformers. Erasmus, in Praise of Folly, drew jesting analogies between the way that the saints were understood in popular Catholicism and the cult of the gods in paganism. ${ }^{58} \mathrm{In}$ his colloquy Shipwreck, Erasmus explained the devotion to Mary as "Star of

\footnotetext{
${ }^{52}$ De Origine Erroris, chs. 1-6, 8-12.

${ }^{53}$ Ibid., ch. 14 , fo. $59 \mathrm{v}$.

${ }^{54}$ Ibid., chs. $15-17$.

${ }^{55}$ Ibid., ch. 24 , fos. $116 \mathrm{v}-117 \mathrm{r}$.

${ }^{56}$ Ibid., chs. 25-26.

${ }^{57}$ Bartlett, Why can the Dead Do Such Great Things?, 609-618, and compare Peter Brown, The Cult of the Saints: Its Rise and Function in Latin Christianity (Chicago: University of Chicago Press, 1981), xvi-xvii, 20-22.

${ }^{58}$ Desiderius Erasmus, The Praise of Folly, trans. with commentary by Clarence H. Miller (New Haven, Conn.: Yale University Press, 1979), 63-64.
} 
the Sea" as a direct carry-over from the legend of the sea-born goddess Venus, "the mother who was not a virgin."

Bullinger took over this humanist skepticism about the popular understanding of the saints and developed it wholesale. ${ }^{60}$ Some saints, like pagan deities, dealt with the conditions necessary to life, as Agatha and Florian protected against fire, Nicholas and Christopher against shipwreck, Jodocus against blight of cereal crops. Geese were looked after by Gallus, sheep by Windelin, horses by Eulogius, cows by Pelagius, pigs by Antony, Gertrude protected against infestations of mice. Different professions had their tutelary saints; different diseases had their specialist physicians. Deploying impressive classical literary knowledge, Bullinger embarked in his chapter 35 on a "comparison between images, temples, sacrifices, feasts, and offerings among Christians and pagan superstitions."61

The reformers were therefore deeply hostile to the belief that the especially holy dead could hear our requests in heaven and serve as intercessors in times of need. They were deeply averse to the practice of venerating the images of saints as though those images contained, represented, or localized the saint's numinous being. However, there has been something of a vogue in recent decades for observing how some of the cultural needs that the medieval church had supplied were not entirely abolished in the changes of the Reformation. Sixteenth-century Protestants were still living in an emphatically premodern world. It may, therefore, be suggestive, or even helpful, to speculate as to what the Protestant successors to the saints may have looked like.

First, as the reformed churches took shape and established themselves, it became increasingly important to demonstrate that the Reformation was not a novelty, that the reformed were, in fact, merely restoring the church to its purity, sullied by the contaminations of the Middle Ages. Since all believed that the true church was continuous, the reformers found their successors, the conservators of the true faith, in some of the dissenters and "heretics" identified and persecuted by the medieval church and papacy, between the putative decline of the visible church in the Middle Ages and its restoration at the Reformation. (Conveniently, the rise of inquisitions against heresy coincided fairly closely with the papacy of Innocent III and the beginnings of the friars.) Works such as Flacius Illyricus's Catalogue of Witnesses to the Truth of 1556 helped establish this idea of doctrinal antecedents to the

\footnotetext{
${ }^{59}$ Desiderius Erasmus, Colloquies, ed. and trans. Craig R. Thompson (Toronto: University of Toronto Press, 1997), 351-367, and esp. 355.

${ }^{60}$ De Origine Erroris, ch. 34 , fo. $164 \mathrm{r}$ : "Comparison between the pagan gods and the Christian saints, to both of which care of the elements, animals, diseases, arts, and finally all aspects of people are thought to be entrusted."

${ }^{61}$ Ibid., ch. 35 , fos. $167 \mathrm{v}-172 \mathrm{r}$.
} 
reformers. ${ }^{62}$ They were not saints in the traditional sense, but even so, John Milton, in his sonnet on the massacred Waldensians of Piedmont in 1655, called on God to "avenge, O Lord, thy slaughtered saints."

Second (and as Bartlett has observed) the reformers fairly rapidly began to collect and to commemorate their own martyrs who had suffered in persecution, as the early church had done. Such heroic figures were not prayed to, were not given particular post-mortem assignments to help the living, and were not celebrated with images, altars, and candles. Nevertheless, one can without too much of a stretch imagine that the reading of a martyrology such as those of Foxe or Crespin, might have played a somewhat similar role in a reformed household, as the reading of a hagiography had done in a medieval monastery. In 1570 the Privy Council directed the archbishops of Canterbury and York and the bishop of London to have the latest edition of Foxe's Martyrs placed in parish churches; in 1571 Canterbury Convocation decreed that prelates and archdeacons should acquire their own personal copies. ${ }^{63}$

Then there is the question of iconography. Yes, the Protestants-Lutherans included, though they were generally willing to leave medieval imagery in place-would never use images as cult objects to say services before, to carry in procession, to illuminate with candles, or to pray before. However, the churches of the Reformation, Lutheran and reformed alike, certainly had no objection to portraiture. Martin Luther was one of the most frequently painted human beings in the history of the West up to his time, Jesus and the most major saints alone excluded. Engravings based on portraits of the reformers were often reproduced and widely collected and distributed. Heinrich Bullinger (leader of the most iconophobic of all reformed churches) drew attention to this trend, pointing out how dissimilar it was from the medieval cult of saints, but therefore closer (he believed) to the use of images in early Christian antiquity: "We see nowadays some students carry around icons of Erasmus, Luther and Zwingli, which they do not adore, they do not place in churches, they place no incense before, and they do not think to receive anything from them, but because they love them as living people and know that they have been of great benefit to learning and religion,

\footnotetext{
${ }^{62}$ Matthias Flacius Illyricus, Catalogus testium Veritatis, Qui ante nostram aetatem reclamarunt Papae (Basel: per Ioannem Oporinum, 1556). On this subject see also Euan Cameron, "Medieval Heretics as Protestant Martyrs," in Martyrs and Martyrologies: Papers read at the 1992 Summer Meeting and the 1993 Winter Meeting of the Ecclesiastical History Society, ed. Diana Wood, Studies in Church History, vol. 30 (Oxford: Published for the Ecclesiastical History Society by Blackwell Publishers, 1993),185-207.

${ }^{63}$ John N. King, Foxe's Book of Martyrs and Early Modern Print Culture (Cambridge: Cambridge University Press, 2006), 112-113.
} 
therefore they keep their images close to them as indications of love, not as instruments of religion.",64

In 1580, Theodore Beza would publish, as the Icones, a large collection of such portraits; and the production of these images would continue well on into the seventeenth century and beyond. ${ }^{65}$ Moreover (whatever theological orthodoxy might say about the insufficiency of our sanctification), the images were usually accompanied by short poems celebrating the virtues and achievements of their subjects.

Over time the churches of the Reformation have allowed sainthood to slide off into commemoration, and the scope of individuals to be commemorated has been considerably enlarged in the process. Great scholars and teachers of the faith, missionaries, exponents of sacrificial self-giving in the service of the poor and needy, mystics and founders of religious movements rub shoulders with the apostles, martyrs, heroic ascetics and confessors, and founders of Christianity in different parts of the world. Commemoration sometimes makes strange bedfellows, as when the Church of England commemorates both Thomas More and William Tyndale. ${ }^{66}$ Commemoration makes no speculation about the post-mortem ministries of those it celebrates. It requires no miracles, nor other evidence of heavenly intercession.

By way of conclusion, and recognizing that these questions fall far outside the already very generous boundaries of Robert Bartlett's magnificent book, perhaps we should always see sainthood as in dialogue with the broader issue of commemorating lives well-lived in the faith. In our own lifetimes there has been a somewhat bewildering change in canonization practices in Roman Catholicism. After a period of extreme caution and reserve in the four hundred years or so after 1523, when canonization was conducted sparingly and with great care, the later twentieth century saw something like an explosion of sanctity. John Paul II famously canonized more saints than any of his predecessors put together. Benedict XVI continued this generous trend. Francis has recently canonized two of his predecessors of living memory. While the Congregation of Rites doubtless continues to be as thorough and scrupulous as ever, it is hard not to speculate that sainthood is at least partly shading off into commemoration, even in the Roman Catholic tradition itself.

\footnotetext{
${ }^{64}$ Bullinger, De Origine Erroris, fo. 114r.

${ }^{65}$ Theodore Beza, Icones, id est verae imagines virorum doctrina simul et pietate illustrium (Geneuae: apud I. Laonium, 1580).

${ }^{66}$ See https://www.churchofengland.org/prayer-worship/worship/texts/the-calendar/holydays.aspx, accessed June 28, 2016. Thomas More is commemorated on 6 July, William Tyndale on 6 October. Tyndale, it should be said, is awarded a festival; More receives only a commemoration.
} 